\title{
INFLUENCE OF PRODUCTION SEASON AND LACTATION STAGE ON THE TECHNOLOGICAL SUITABILITY OF MILK FROM COWS OF VARIOUS BREEDS FED IN THE TMR SYSTEM*
}

\author{
Joanna Barłowska ${ }^{1 \bullet}$, Zygmunt Litwińczuk ${ }^{2}$, Monika Kowal ${ }^{2}$ \\ ${ }^{1}$ Department of Commodity Science and Processing of Raw Animal Materials, \\ ${ }^{2}$ Department of Breeding and Protection of Genetic Resources of Cattle, \\ University of Life Sciences, Akademicka 13, 20-950 Lublin, Poland \\ •Corresponding author: joanna.barlowska@up.lublin.pl
}

\begin{abstract}
The aim of the study was to evaluate selected indicators of the technological suitability of milk from four breeds of cow housed in free-stall barns and fed in a TMR system. A total of 1,146 milk samples were analysed, collected from cows of the breeds Polish Holstein-Friesian (Black-and-White and Red-and-White populations), Jersey, and Simmental. The following were determined in the samples: content of solids non-fat and casein, protein-to-fat ratio, active and potential acidity, heat stability, rennet clotting time, and milk fat dispersion. Despite the use of a mono-diet (TMR) year round, somewhat higher daily milk yield was obtained in the spring/summer season, but the differences were statistically significant $(\mathbf{P} \leq \mathbf{0 . 0 1})$ only in the case of PHF RW. The milk obtained in the autumn/winter season contained more solids-non-fat, including casein, and in the case of $\mathrm{JE}$ and PHF $\mathrm{HO}$ the differences were statistically significant $(\mathrm{P} \leq \mathbf{0 . 0 1})$. It also had significantly higher heat stability and a longer rennet clotting time $(\mathrm{P} \leq \mathbf{0 . 0 1})$, with the greatest differences noted in the case of the SM breed. Milk from this period also had a higher percentage of fat globules with a diameter $\geq 6 \mu \mathrm{m}$. The concentration of solids-non-fat, including casein, increased significantly $(P \leq 0.01)$ over the course of lactation in all of the breeds evaluated. The stage of lactation did not significantly affect clotting time, heat stability, or milk fat dispersion.
\end{abstract}

Key words: technological suitability of milk, cattle breeds, TMR feeding system, production season, lactation stage

About one third of cow milk produced worldwide (Guinee, 2003) is used in the production of over 18 million tonnes of cheese (FAOSTAT, 2013). Most cheeses are produced by enzyme coagulation, and thus an important factor determining the suitability of milk for cheese production is rennet clotting time. Coagulation time and

*This study was financed from statutory activity. 
curd firmness are mainly determined by the composition of the milk (Jensen et al., 2012; Cassandro et al., 2008). The firmness of the casein curd is strongly correlated with casein content and the proportions of each of its fractions (Wedholm et al., 2006; Hallén et al., 2007), while rennet clotting time is not entirely correlated with casein content (Wedholm et al., 2006; Frederiksen et al., 2011). Content of mineral salts in the structure of the casein micelles is also a factor (Jensen et al., 2012). Milk from cows with the $\mathrm{B} \kappa-\mathrm{CN}, \beta-\mathrm{CN}$ or $\beta-\mathrm{LG}$ variant is also believed to have more beneficial properties for cheese production (Di Stasio and Mariani, 2000; Jensen et al., 2012; Bittante et al., 2012). Many studies indicate that apart from these direct factors, suitability of milk for cheese production is also influenced by the breed of cow (Chiofalo et al., 2000; Auldist et al., 2004; Tyrisevä et al., 2004; De Marchi et al., 2007; Jõudu et al., 2007; Barłowska and Litwińczuk, 2006; Litwińczuk et al., 2012; Jensen et al., 2012). Bittante et al. (2012) generalize that milk obtained from cow breeds that arose in south-central Europe, particularly in the Alps, has shorter clotting times and higher curd firmness than milk from breeds from northcentral Europe. Other factors, such as lactation stage and the somatic cell count in the milk, also affect milk coagulation properties (Ikonen et al., 2004; Penasa et al., 2014; Pretto et al., 2012).

Production of many long-shelf-life dairy products requires the application of high temperatures, so the heat stability of milk is an important indicator of its technological suitability. If heat stability is too low, the organoleptic properties of the finished product may be compromised due to sedimentation of denatured proteins, and in extreme cases long storage time can result in gelification (Faka et al., 2009).

Also important for technological suitability is the dispersion of milk fat, as the diameter of the fat globules affects the quality of the finished dairy products. Highquality butter is easier to produce from milk with a high percentage of large fat globules, because the churning process is faster, the butter contains less protein and water, which accelerate rancidification, and it is yellower, softer, more spreadable, and lower in cholesterol (Dewettinck, 2008). A higher percentage of large fat globules in milk fat also facilitates the production of hard cheeses, which age faster and are less hydrated, harder, denser and firmer (Michalski et al., 2004).

Intensive milk production systems generally use pure dairy cow breeds, mainly Holstein-Friesian and Jersey. Some farmers attempt to use dual-purpose breeds as well, such as Simmental. Simmental cows raised in traditional systems (with pasture feeding) produce milk with good cheese production parameters (Bittante et al., 2012; De Marchi et al., 2007; Perišić et al., 2009; Sturaro et al., 2012). There is little information, however, on whether milk from Simmental cows retains its high technological suitability in intensive farming systems (TMR feeding).

The aim of the study was to evaluate selected indicators of the technological suitability of milk from four breeds of cow housed in free-stall barns and fed in a TMR system, taking into account the production season and stage of lactation. 


\section{Material and methods}

The study was carried out on 5 farms in south-eastern Poland. The cows were housed in free-stall barns without litter, with resting boxes separated by barriers and mats for bedding, except for the Simmentals, which had no boxes and lay on straw. In all barns manure was removed with a yard scraper, except for one (housing the Jersey herd) in which a hydraulic manure scraper was used. All of the barns had milking parlours (herringbone, with the exception of one tandem milking parlour, in a barn housing Polish Holstein-Friesian Black-and-White cows). The average productivity of the cows in the herds analysed is presented in Table 1. In most of the barns cows were milked and fodder was supplied from a feeding wagon twice a day. The composition of the TMR ration was the same throughout the year. The percentages of each type of fodder depending on the lactation period are presented in Table 2.

Table 1. Productivity of cows in the herds analysed and types of milking parlours

\begin{tabular}{l|c|c|c|c|c}
\hline \multirow{2}{*}{ Breed } & \multicolumn{4}{|c}{ Productivity of cows according to PFCBDF data for 2010 } \\
\cline { 2 - 6 } & $\begin{array}{c}\text { number of cows } \\
\text { in herd } \\
\text { (approx.) }\end{array}$ & $\begin{array}{c}\text { milk yield for } \\
305 \text { days } \\
\text { of lactation } \\
(\mathrm{kg})\end{array}$ & $\begin{array}{c}\text { fat } \\
(\%)\end{array}$ & $\begin{array}{c}\text { protein } \\
(\%)\end{array}$ & $\begin{array}{c}\text { type of milking } \\
\text { parlour }\end{array}$ \\
\hline $\begin{array}{l}\text { Polish Black-and-White } \\
\text { Holstein-Friesian }\end{array}$ & 80 & 8.775 & 4.04 & 3.37 & Herringbone \\
Polish Black-and-White & & & & & Tandem \\
Holstein-Friesian & 80 & 8.706 & 4.06 & 3.37 & Herringbone \\
$\begin{array}{l}\text { Polish Red-and-White } \\
\text { Holstein-Friesian }\end{array}$ & 130 & 7.195 & 4.18 & 3.73 & Herringbone \\
Jersey & 140 & 7.071 & 5.47 & 3.92 & Herringbone \\
Simmental & 200 & 8.504 & 3.81 & 3.52 & \\
\hline
\end{tabular}

Tabela 2. Composition of TMR ration (\%) depending on the lactation period

\begin{tabular}{l|c|c}
\hline \multicolumn{1}{c|}{ Type of fodder } & $\begin{array}{c}\text { First lactation period } \\
\text { (to approx. 100 days) }\end{array}$ & $\begin{array}{c}\text { Second lactation period } \\
(>100 \text { days to dry period) }\end{array}$ \\
\hline Maize silage & 50 & 55 \\
Haylage & 28 & 35 \\
Grain meal & 11 & 2 \\
Rapeseed meal & 7 & 4 \\
Soybean meal & 4 & 4 \\
Total & 100 & 100 \\
\hline
\end{tabular}

The cows were subjected to use value assessment for dairy cattle and met the requirements for milk production established by Commission Regulation (EC) No. 1662/2006 of 6 November 2006, amending Regulation (EC) No. 853/2004 of the European Parliament and of the Council laying down specific hygiene rules for food of animal origin.

The material for the study consisted of 1146 milk samples collected from cows of the following breeds: Polish Black-and-White Holstein-Friesian (269 samples), Polish Red-and-White Holstein-Friesian (302), Jersey (335), and Simmental (240). The milk samples were collected from cows in second and third lactations. The sam- 
pling was done individually from one day's milk obtained from each cow, twice during the course of one year (in the spring/summer and autumn/winter seasons), into 250-ml plastic bottles. Samples from cows with diseased udders were eliminated. The milk was transported in thermal bags with freezer packs to the laboratory of the Department of Commodity Science and Processing of Raw Animal Materials, University of Life Sciences in Lublin (AOAC, 2000 b).

The following were determined in each milk sample: content of solids-non-fat using a Bentley Infrared Milk Analyzer and casein according to AOAC (2000 a); active acidity $(\mathrm{pH})$ using a Pioneer $65 \mathrm{pH}$ meter (Radiometer Analytical); potential acidity ( $\left.{ }^{\circ} \mathrm{SH}\right)$ by the titration method according to PN-86/A-86122; heat stability at $140^{\circ} \mathrm{C}$ in a TEWES-BIS oil bath using White and Davies' method; rennet clotting time by Schern's method (A $0.25 \mathrm{~cm}^{3}$ volume of a 1:1,000 rennet solution was added to $25 \mathrm{~cm}^{3}$ of milk heated to $35^{\circ} \mathrm{C}$. The sample was mixed and placed in a water bath at $35^{\circ} \mathrm{C} \pm 0.5^{\circ} \mathrm{C}$, and observed until the moment when the first casein floccules formed); and the percentage of fat globules in three size ranges: $<6 \mu \mathrm{m}, 7-10 \mu \mathrm{m}$ and $>10 \mu \mathrm{m}$ (by microscopy at $1000 \times$ magnification in smears stained with Sudan III) (Litwińczuk, 2011). The proportion of protein to fat in the samples was calculated as well. Somatic cell count (SCC) was determined using a Bentley Somacount 150 apparatus, in order to eliminate milk samples with SCC above 400,000/ml.

Data on the daily milk yield of the cows was obtained from breeding documentation conducted by the Polish Federation of Cattle Breeders and Dairy Farmers.

The data regarding milk yield and selected traits of milk technological suitability were subjected to analysis of variance (ANOVA) using the GLM procedure of STATISTICA ver. 6 (StatSoft, 2003). For statistical analysis, two models were used. The first model with fixed effects included cow breed, production season, and interaction, according to the following linear model:

where:

$$
Y_{i j k}=\mu+G_{i}+S_{j}+\left(G_{i} \times S_{j}\right)+e_{i j k}
$$

$\mu$ - overall mean,

$G_{i}$ - cow breeds (i = PHF HO, PHF RW, SM, JE),

$S_{j}$ - production season $(\mathrm{j}=$ spring/summer, autumn/winter $)$,

$\left(G_{i} \times S_{j}\right)$ - interaction cow breeds $\times$ production season,

$e_{i j k}-$ the effect of random error.

The second model included breed, stage of lactation, and interaction, according to the following linear model:

where:

$$
Y_{i l m}=\mu+G_{i}+L_{l}+\left(G_{i} \times L_{\nu}\right)+e_{i l m}
$$

$\mu$ - overall mean,

$G_{i}$ - cow breeds (i = PHF HO, PHF RW, SM, JE),

$L_{l}$ - stage of lactation ( $1=$ up to $120,121-200$, over 200 days of lactation),

$\left(G_{i} \times L_{\nu}\right)$ - interaction cow breeds $\times$ stage of lactation,

$e_{i l m}-$ the effect of random error. 
Multiple comparison of the means was performed using Tukey's HSD test. The level of significance was set to $\mathrm{P} \leq 0.05$ or $\mathrm{P} \leq 0.01$.

\section{Results}

The data in Table 3 show that the highest daily yield was observed in the cows of the Black-and-White population of the Holstein-Friesian breed $(25.8 \mathrm{~kg})$, and the lowest in the Jerseys $(21.65 \mathrm{~kg})$. Milk yield in the Simmental cows was at an intermediate level $(23.2 \mathrm{~kg})$. Cows of all the breeds produced more milk in the spring/ summer season, but the differences were statistically significant $(\mathrm{P} \leq 0.01)$ only in the case of the Red-and-White population of Polish Holstein-Friesians. The milk of the Jersey cows stood out in terms of its content of components determining cheese yield (Table 3$)$. It contained significantly $(\mathrm{P} \leq 0.01)$ the most solids-non-fat $(9.60 \%)$ and casein $(3.07 \%)$, but had the least beneficial protein-to-fat ratio $(0.80)$. The milk of the Simmental cows had a high concentration of casein $(2.92 \%)$ and at the same time the significantly $(\mathrm{P} \leq 0.05)$ most beneficial protein-to-fat ratio (0.86). Analysis of seasonal changes in the content of the milk components (Table 3) showed that the concentration of solids-non-fat and casein and the protein-to-fat ratio were always higher in the autumn/winter season, although statistically significant differences were noted only in the case of the Black-and-White Polish Holstein-Friesian and Jersey cows $(\mathrm{P} \leq 0.01)$.

The longest clotting time was observed in the milk of the Simmental breed (348 s), and was about $60 \mathrm{~s}$ longer than in the other breeds (Table 3 ). This milk also had the lowest active and potential acidity $\left(6.72 \mathrm{pH}\right.$ and $\left.6.85^{\circ} \mathrm{SH}\right)$, while the highest acidity was noted in the Jersey cows (6.62 $\mathrm{pH}$ and $\left.7.46^{\circ} \mathrm{SH}\right)$. Milk obtained in the spring and summer months generally had a significantly shorter $(\mathrm{P} \leq 0.01)$ rennet clotting time and higher active and potential acidity ( $\mathrm{pH}$ and $\left.{ }^{\circ} \mathrm{SH}\right)$. The best heat stability $(\mathrm{P} \leq 0.01)$ was noted in the Black-and-White Polish Holstein-Friesian cows $(220 \mathrm{~s})$, while the milk of the Jersey cows was most susceptible to thermal destabilization (140 s). Milk from all 4 breeds had significantly higher $(\mathrm{P} \leq 0.01)$ heat stability in the autumn and winter months (Table 3 ).

The milk of the Black-and-White Polish Holstein-Friesian cows had significantly $(\mathrm{P} \leq 0.01)$ the highest percentage of small fat globules $(68.87 \%)$, while the milk fat of the Jersey cows had the highest percentage of medium-sized $(\mathrm{P} \leq 0.01)$ and large $(\mathrm{P} \leq 0.05)$ fat globules $(35.41 \%$ and $12.73 \%$, respectively), and significantly the lowest percentage $(\mathrm{P} \leq 0.01)$ of small ones $(52 \%)$. In the milk of the other breeds, the percentage of fat globules in each size range attained intermediate values. Significant $(\mathrm{P} \leq 0.01)$ differences in milk fat dispersion were noted between production seasons. In the autumn/winter months the percentage of fat globules of $\geq 6 \mu \mathrm{m}$ diameter increased in all of the breeds evaluated (Table 3 ). 


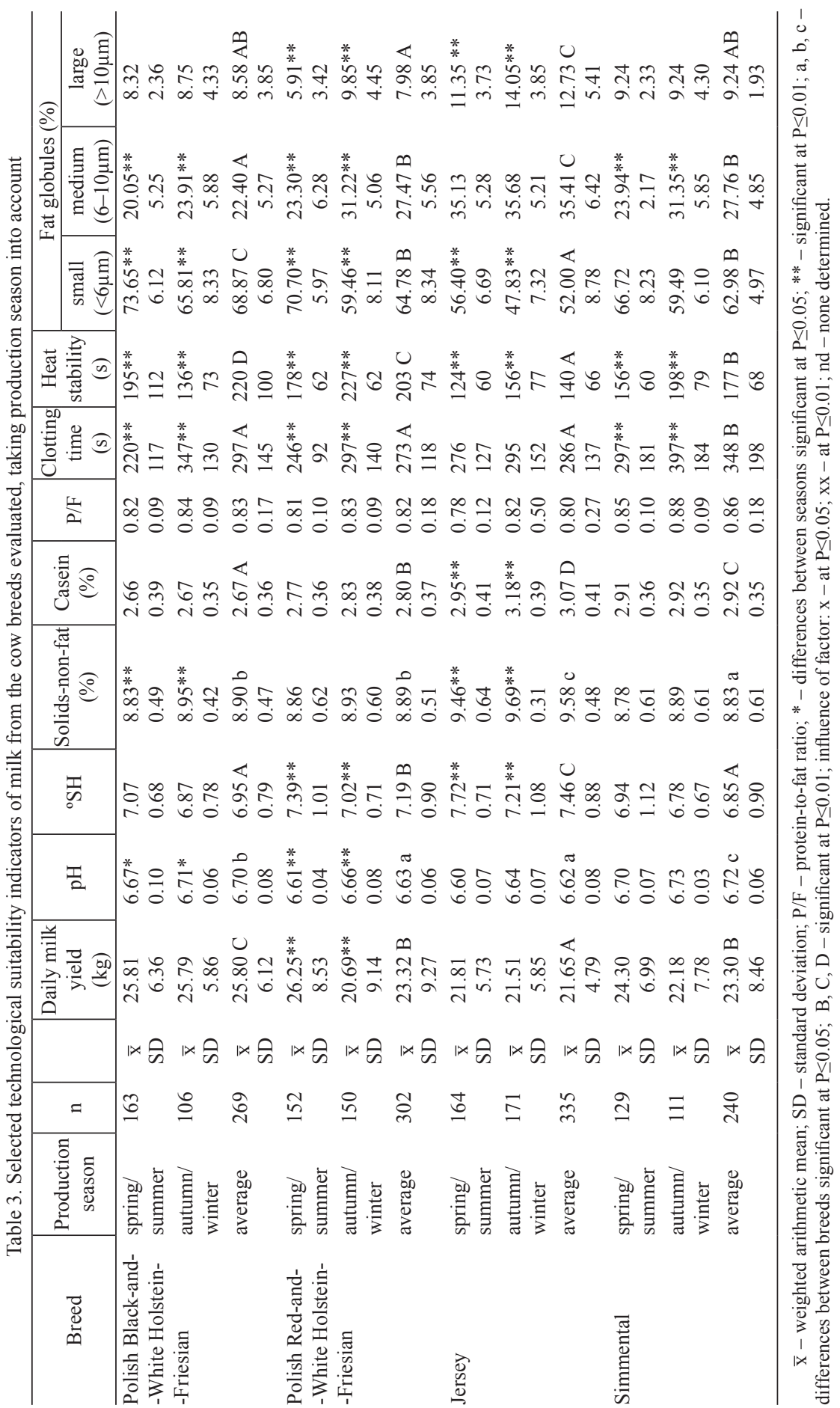




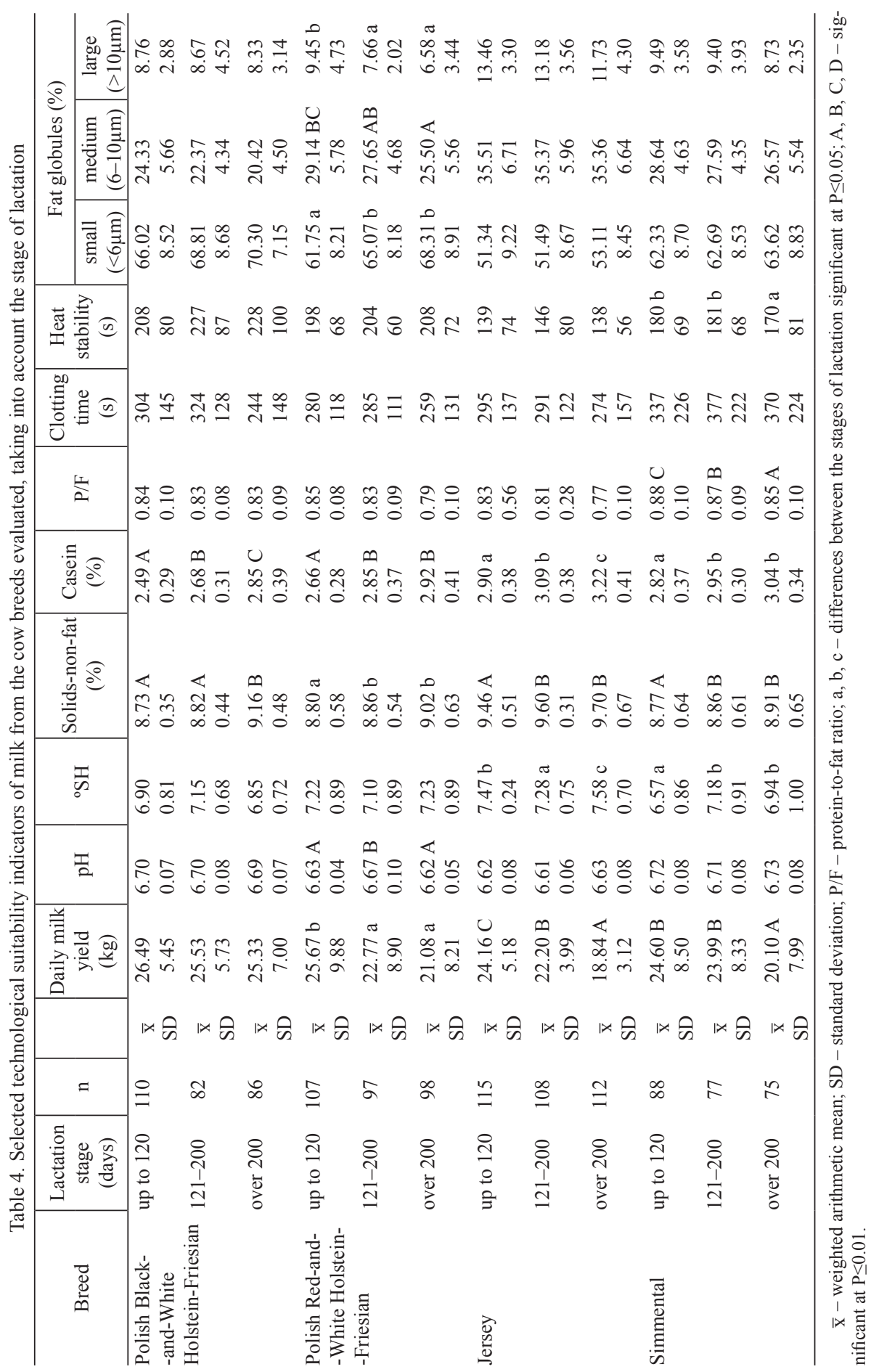




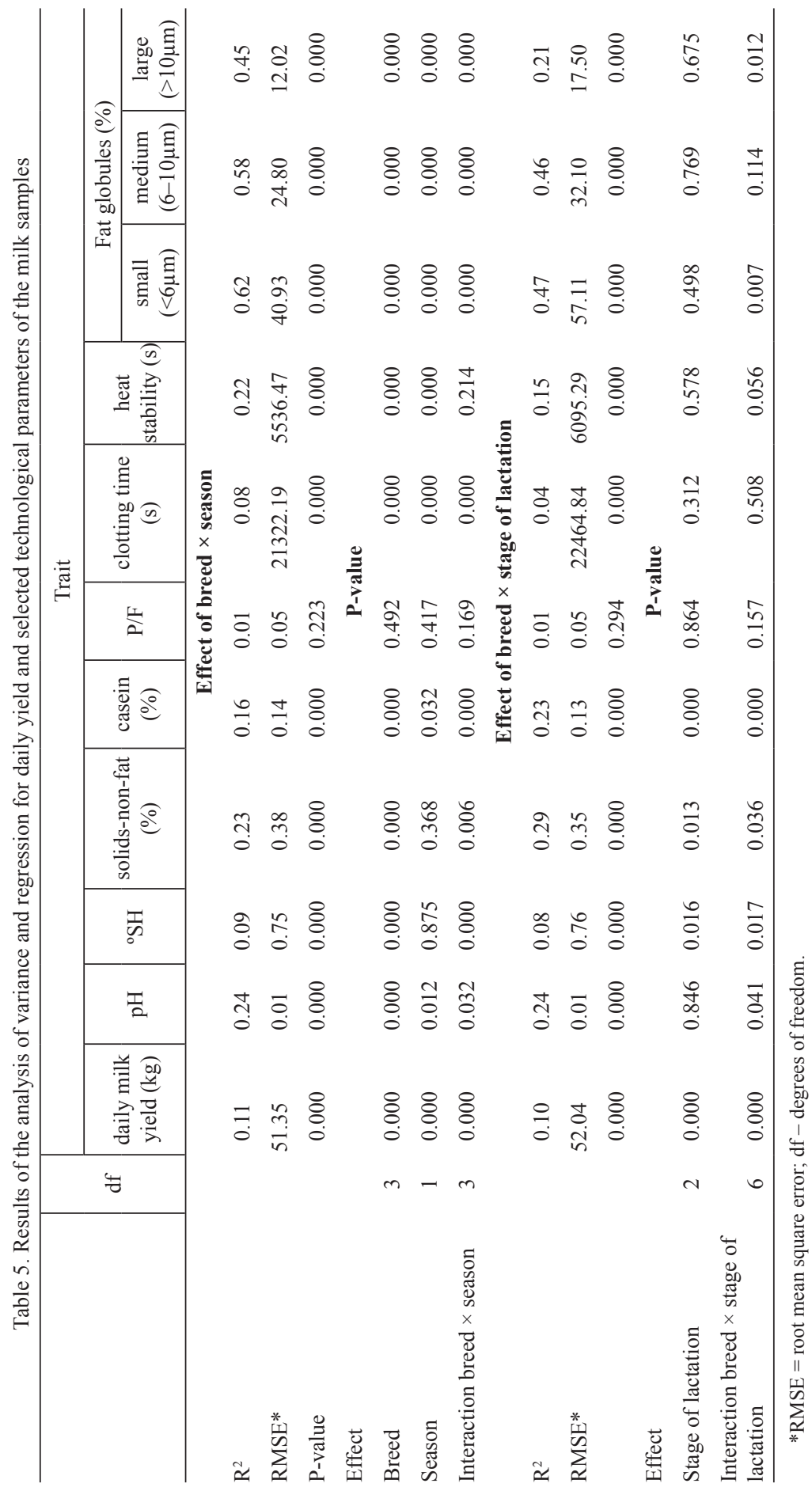


The data in Table 4 show that in all of the breeds evaluated daily milk yield decreased over the course of lactation. In the Jersey, Red-and-White Holstein-Friesian and Simmental breeds the decrease was relatively large $-5.32,4.59$ and $4.50 \mathrm{~kg}$, respectively $(\mathrm{P} \leq 0.01)$, while in the Polish Black-and-White Holstein Friesians it was smaller $(1.16 \mathrm{~kg})$ and statistically insignificant. Over the course of lactation the concentration of casein and solids-non-fat in the milk increased significantly $(\mathrm{P} \leq 0.01$ and $\mathrm{P} \leq 0.05$ ). In the case of solids-non-fat, the differences between the first and third stage of lactation ranged from $0.14 \%$ in the milk of the Simmentals to $0.43 \%$ in the Polish Black-and-White Holstein Friesians, and the casein content was $0.22 \%$ and $0.36 \%$, respectively. The percentage of large and medium-sized fat globules also showed a downward trend, but this was not confirmed statistically.

Analysis of the simultaneous influence of breed and production season showed highly significant interactions $(\mathrm{P} \leq 0.01)$ for daily milk yield, potential acidity, casein content, concentration of solids-non-fat, rennet clotting time, and milk fat dispersion, as well as significant interactions $(\mathrm{P} \leq 0.05)$ for active acidity (Table 5). Significant breed $\times$ lactation-stage interactions were noted for daily milk yield $(\mathrm{P} \leq 0.01)$, while for most of the technological suitability parameters analysed, with the exception of casein content and percentage of small fat globules $(\mathrm{P} \leq 0.01)$ and solids-non-fat content and potential acidity $(\mathrm{P} \leq 0.05)$, no interactions between these factors were found (Table 5).

\section{Discussion}

All four breeds of cow evaluated, fed in a TMR system, exhibited relatively high daily milk yield (22-26 kg), but with some significant differences between breeds, which are confirmed in a study by Brodziak et al. (2012). Although the cows were fed a mono-diet year round (TMR), somewhat higher daily milk yield was observed in the spring/summer season, and in the case of the Red-and-White Holstein-Friesian cows the differences were significant $(\mathrm{P} \leq 0.01)$. Similar tendencies have been reported by Strzałkowska et al. (2010) and Brodziak et al. (2012). A high concentration of basic components in the milk of Jersey cows was also noted by White et al. (2001). Guinee (2003) states that the milk of these cows is the best raw material for cheese production, as it coagulates faster, the curd obtained is firmer, and the cheese yield is higher.

The differences in milk composition between the spring/summer and autumn/ winter seasons were small because the same set of TMR feeds was used all year. This eliminated the seasonal differences characteristic of traditional feeding, in which pasture grazing is a substantial element. However, most authors (Król et al., 2010; Strzałkowska et al., 2010; Brodziak et al., 2012) confirm that the milk of cows of different breeds fed in a TMR system has a more beneficial chemical composition in the autumn/winter season.

A significant factor in the production of rennet cheeses is enzyme coagulation time, which significantly influences the firmness of the curd. The observation of 
the longest coagulation time in the Simmental breed (on average about 1 minute longer than in the other breeds) does not find confirmation in an earlier study by Litwińczuk et al. (2012). The authors evaluated milk from cows of three breeds included in the genetic resources conservation programme (Polish Red, White-Backed and Polish Black-and-White), and as a reference, Polish Holstein-Friesians kept in intensive farming systems and conventionally-fed Simmentals. They noted the longest rennet clotting time in the milk of the Holstein-Friesian cows (297 s). The milk of the Simmentals fed in a conventional manner, with a diet based on pasture forage, clotted significantly $(\mathrm{P} \leq 0.01)$ faster (compared to the Polish Red and Polish Black-and-White), i.e. about $140 \mathrm{~s}$ faster than the milk of the Simmentals in the present study. The fact that in the present study the longest clotting time was noted in the intensively-farmed Simmentals may result from the use of maize silage and dried grass year round, rather than fresh grass in the summer and hay in the winter.

In the present study, rennet clotting time was generally significantly shorter $(\mathrm{P} \leq 0.01)$ in the spring and summer months, which is confirmed by an earlier study by Barłowska et al. (2012). De Marchi et al. (2007) also observed a shorter clotting time in the summer months in milk from 5 breeds of cows (Holstein-Friesian, Brown Swiss, Simmental, Rendena and Alpine Gray). In studies by Jõudu et al. (2007) and St-Gelais and Hache (2005), the milk with the longest rennet coagulation time was found to be highly resistant to the effects of high temperature. This is partially confirmed by our study, in which the milk of the Simmental cows, which had the longest enzyme coagulation time, had relatively high heat stability (Table 3 ). The significantly higher $(\mathrm{P} \leq 0.01)$ heat stability noted in the present study for the milk of TMR-fed cows in the autumn/winter season is confirmed by earlier studies by the authors (Barłowska and Litwińczuk, 2006), as well as by studies on milk obtained in traditional feeding systems, i.e. pasture.

The fact that the percentage of larger fat globules increased in the autumn and winter months is confirmed by Michalski et al. (2004), who reported that in the winter the average diameter of fat globules was greater (as much as 7-fold) than in the spring, so that the surface area $\left(\mathrm{m}^{2}\right)$ of $1 \mathrm{~g}$ of fat globules in individual samples of spring milk was as much as 10 times higher than in winter milk.

The stage of lactation did not significantly influence most of the technological suitability indicators analysed, with the exception of concentration of solids-nonfat, including casein. Ikonen et al. (2004) found that milk from the middle stage of lactation coagulated the most slowly. A similar relationship was observed by Harzia et al. (2013), who found that milk at the beginning of lactation coagulated fastest, after which its clotting time increased continually until the 8th month of lactation, decreasing slightly during the final period. Penasa et al. (2014) found that rennet clotting time increased up to day 90 of lactation, and then decreased somewhat after day 210. Frederiksen et al. (2011), assessing the milk of cows of three breeds (Danish Holstein-Friesian, Danish Red and White, and Danish Jersey) maintained in free-stall barns and fed a TMR system, found significant $(\mathrm{P} \leq 0.001)$ differences between breeds in rennet coagulation time; however, no effects of lactation day (as in the present study), and lactation number on this parameter were shown. This may be 
the result of husbandry technology used (free-stall barns and TMR feeding system), similar to the herds of cows included in the present study.

To sum up, in the milk production technology used, i.e. free-stall housing and TMR feeding, the production season (spring/summer and autumn/winter) influenced daily milk yield and casein content, but above all differentiated its technological suitability indicators $(\mathrm{P} \leq 0.01)$, i.e. rennet clotting time and heat stability. The greatest differences in this regard were noted for daily milk yield in the PHF RW breed, for casein content in JE, and for clotting time and heat stability in SM. The stage of lactation generally did not significantly influence the technological suitability indicators analysed, i.e. its clotting time, heat stability and fat dispersion. Analysis of the simultaneous influence of breed and production season showed highly significant interactions $(\mathrm{P} \leq 0.01)$ for daily milk yield, potential acidity, casein content, concentration of solids-non-fat, rennet clotting time, and milk fat dispersion, as well as significant interactions $(\mathrm{P} \leq 0.05)$ for active acidity. However, for most of the technological suitability parameters analysed, with the exception of casein content and percentage of small fat globules $(\mathrm{P} \leq 0.01)$ and solids-non-fat content and potential acidity $(\mathrm{P} \leq 0.05)$, no interactions between these factors were found.

\section{References}

AOAC (2000 a). Official Methods of Analysis. Casein Nitrogen Content of Milk. 998.06. AOAC International, Chapter 32, 52.

AOAC (2000 b). Official Methods of Analysis. Collection of Milk Laboratory Sample. 925.20. AOAC International, Chapter $33,4$.

A u ld is t M.J., Johnst on K.A., Wh it e N.J., F it z s i mon s W.P., B o l and M.J. (2004). A comparison of the composition, coagulation characteristics and cheesemaking capacity of milk from Friesian and Jersey dairy cows. J. Dairy Res., 71: 51-57.

B arłowska J., Litwiń c zuk Z. (2006). Technological usefulness of milk from two local breeds maintained in the regions with great grassland share. Arch. Tierzucht., 49: 207-213.

Barłowska J., Litwińczuk Z., Brodziak A., Chabuz W. (2012). Effect of the production season on nutritional value and technological suitability of milk obtained from intensive (TMR) and traditional feeding system of cows. J. Microb. Biotech. Food Sci., 1: 1205-1220.

Bittante G., Penas a M., Cec chinato A. (2012). Invited review: Genetics and modeling of milk coagulation properties. J. Dairy Sci., 95: 6843-6870.

Brodziak A., Litwińczuk A., Topyła B., Wolanciuk A. (2012). Influence of production season $\times$ breed and feeding system interactions on daily yield and milk physical-chemical composition (in Polish). Scient. Ann. Pol. Soc. Anim. Prod., 8: 19-27.

Cassandro M., Comin A., Ojala M., Dal Zotto R., De Marchi M., Gallo L., Car$\mathrm{n}$ i er P., B ittante G. (2008). Genetic parameters of milk coagulation properties and their relationships with milk yield and quality traits in Italian Holstein cows. J. Dairy Sci., 91: 371-376.

Ch i of a 1 o V., Mald on a to R., M a r t in B., D u p o in t D., C o u 1 on J.B. (2000). Chemical composition and coagulation properties of Modicana and Holstein cow's milk. INRA. EDP Sci. Ann. Zootech., 49: 497-503.

De Marchi M., Dal Zotto R., Cas sandro M., B ittante G. (2007). Milk coagulation ability of five dairy cattle breeds. J. Dairy Sci., 90: 3986-3992.

Dewettinck K., Rombaut R., Thienpont N., Trung Le T., Messens K., Camp J.V. (2008). Nutritional and technological aspects of milk fat globule membrane material. Int. Dairy J., 18: $436-57$.

Di S ta s i o L., Maria ni P. (2000). The role of protein polymorphism in the genetic improvement of milk production. Zoot. Nutr. Anim., 26: 69-90. 
Faka M., L e w is M.J., Grandis on A.S., D e eth H. (2009). The effect of free $\mathrm{Ca}^{2+}$ on the heat stability and other characteristics of low-heat skim milk powder. Int. Dairy J., 19: 386-392.

FAOSTAT (2013). Statistics Division (Internet). Food and Agriculture Organization of the United Nations 2011. Available from: http://faostat.fao.org/. Accessed July 29, 2013.

Frederiksen P.D., Hammershøj M., Bakman M., Andersen P.N., Andersen J.B., Q v is t K.B., L a r s e n L.B. (2011). Variations in coagulation properties of cheese milk from three Danish dairy breeds as determined by a new free oscillation rheometry-based method. Dairy Sci. Technol., 91: 309-321.

Gu in e e T.P. (2003). Role of protein in cheese and cheese products. In: Advanced Dairy Chemistry. 1. Proteins, Part B, Fox P.F., McSweeney P.L.H. (eds). Kluwer Academic/Plenum Publisher, 3rd ed., pp. 1083-1174.

Hallen E., A 11 mere T., N a s lund J., A ndren A., Lunden A. (2007). Effect of genetic polymorphism of milk proteins on rheology of chymosin-induced milk gels. Int. Dairy J., 17: 791-799.

Harzi a H., Ilves A., O t s M., Hen no M., J õ u d u I., K a a r t T., L ing K., Kär t O., Kilk K., $\mathrm{S}$ o o m e t s U. (2013). Alterations in milk metabolome and coagulation ability during the lactation of dairy cows. J. Dairy Sci., 96: 6440-6448.

I kon en T., Morry S., Tyris evä A.-M., R outtinen O., Oja la M. (2004). Genetic and phenotypic correlations between milk coagulation properties, milk production traits, somatic cell count, casein content and pH of milk. J. Dairy Sci., 87: 458-467.

Jensen H.B., Poulsen N.A., Andersen K.K., Hammershøj M., Pouls en H.D., Lars e n L.B. (2012). Distinct composition of bovine milk from Jersey and Holstein-Friesian cows with good, poor, or noncoagulation properties as reflected in protein genetic variants and isoforms. J. Dairy Sci., 95: 6905-6917.

J õ u d u I., H e n no M., Varv S., K a a r t T., K a r t O., K a l a m e e s K. (2007). Milk protein genotypes and milk coagulation properties of Estonian native cattle. Agric. Food Sci., 16: 222-231.

Król J., Litwińczuk Z., B rodziak A., S a w i cka-Zugaj W. (2010). Bioactive protein content in milk from local breeds of cows included in the genetic resources conservation programme. Ann. Anim. Sci., 10: 213-221.

L i tw iń c z u k Z. (2011). Methods of commodity evaluation of animal raw materials and products (in Polish). University of Life Sciences Publishing, Lublin, Poland, 246 pp.

Litwińczuk Z., B a rłow s k a J., Chabuz W., B rodziak A. (2012). The nutritional value and technological suitability of milk from cows of 3 Polish breeds included in the programme of genetic resources conservation. Ann. Anim. Sci., 12: 423-432.

Michalski M.C., Camier B., Briard V., Leconte N., Gassi J.Y., Goudédranche H., Michel F., F a u quant J. (2004). The size of native milk fat globules affects physico-chemical and functional properties of Emmental cheese. Lait, 84: 343-358.

Penasa M., Tiezzi F., Sturaro A., Cassandro M., De Marchi M. (2014). A comparison of the predicted coagulation characteristics and composition of milk from multi-breed herds of Holstein-Friesian, Brown Swiss and Simmental cows. Int. Dairy J., 35: 6-10.

Perišić P., Skalicki Z., Petrović M.M., Bogdanović V., Ružić-Muslić D. (2009). Simmental cattle breed in different production systems. Biotechnol. Anim. Husb., 25: 315-326.

Pretto D., López-Villalobos N., Penas a M., Cas sandro M. (2012). Genetic response for milk production traits, somatic cell score, acidity and coagulation properties in Italian HolsteinFriesian population under current and alternative selection indices and breeding objectives. Livestock Sci., 150: 59-66.

$\mathrm{St}-\mathrm{G}$ e $\mathrm{l}$ a i s D., H a c h e S. (2005). Effect of $\beta$-casein concentration in cheese milk on rennet coagulation properties, cheese composition and cheese ripening. Food Res. Int., 38: 523-531.

Strzałkowska N., Jóźwik A., Bagnicka E., Krzyżewski J., Cooper R.G., Horbań czuk J.O. (2010). Cholesterol content of cow milk in TMR system, Mljekarstvo, 60: $273-279$.

Sturaro A., Tiezzi F., Penas a M., De Marchi M., Cas sandro M. (2012). Study of milk coagulation properties in multibreed Italian dairy herds. Acta Agr. Slov., 3: 89-92.

Tyris evä A.M., Vahlsten T., Ru ottinen O., Oja la M. (2004). Noncoagulation of milk in Finnish Ayrshire and Holstein-Friesian cows and effect of herds on milk coagulation ability. J. Dairy Sci., 87: 3958-3966. 
Wedholm A., Larsen L.B., Lindmark-Mansson H., Karlsson A.H., Andren A. (2006). Effect of protein composition on the cheesemaking properties of milk from individual dairy cows. J. Dairy Sci., 89: 3296-3305.

Wh i t e S.L., B ertrand J.A., Wa d e M.R., Wa s hburn S.P., Greek J.T., J en k in s T.C. (2001). Comparison of fatty acid content of milk from Jersey and Holstein cows consuming pasture or a Total Mixed Ration. J. Dairy Sci., 84: 2295-2301.

Received: 17 XII 2013

Accepted: 25 III 2014 